\title{
BESTUURSETIEK IN BESTUURSOPLEIDING: RETORIEK OF REALITEIT
}

\author{
S KRUGER
}

Departement Ondernemingsbestuur

Randse Afrikaanse Universiteit

\begin{abstract}
Business ethics in business training: Oratory or the actuality. This article is the culmination of an in-depth literature study. On the one hand an attempt is made to incorporate the views of different authors, while on the other hand an attempt is made to take part in the debate which is initiated by the current renewal of interest in the subject Business Ethics. Within this framework attention is paid to the question of whether business ethics can be taught and if so, to what extent it's influence will be felt. Secondly, an insight into the teaching of business ethics in the future is provided. Within this context the approach to the teaching, the content, the role of the student and the responsibility of the educator in particular are addressed.
\end{abstract}

\section{OPSOMMING}

Hierdie artikel is die resultaat van ' $n$ indringende literatuurstudie. Daar word gepoog om enersyds verskillende skrywers se standpunte saam te vat, maar andersyds ook kritiese kommentaar te lewer en deel te neem aan die debat wat deur die huidige oplewing in die belangstelling in Bestuursetiek bestaan.

Binne die raamwerk sal aandag aan die volgende geskenk word: Die beantwoording van die vraag of Bestuursetiek onderrig kan word en indien wel die trefwydte daarvan. Tweedens ' $n$ toekomsblik op die onderrig van Bestuursetiek. Binne die konteks word die benadering tot die onderrig, die inhoud en die rol van die student en die verantwoordelikheid van die dosent bekyk.

Daar is onteenseglik spanning tussen die onderneming enersyds en bestuursetiek andersyds. In die woorde van Donaldson en Werhane (1988, p. 1): ". . . the idea of business ethics constitutes a contradiction in terms. 'Business is business', it has been said, 'and ethics is not business'." Elke dag hoor en lees die publiek van onwettige, immorele en onetiese gedrag van bekendes in die sakewêreld. Die media is vol van aanklagte van korrupsie, onwettige handelstransaksies en uitbuiting. Hierdie aanklagte word aan die deur van regslui, medici, politici, staatsamptenare en sakeleiers gelê.

Om die verhouding tussen die onderneming en etiek te verstaan, is dit nodig om begrip te hê vir die feit dat as die fokus hoofsaaklik op doeltreffendheid en die generering van wins val, morele aspekte maklik in die slag kan bly.

Te midde van al die negatiewe beriggewing en publisiteit is daar by sakelui die bereidheid om te erken dat daar oordrewe klem op sukses in terme van geld geplaas word. Die toewyding aan materialisme, wetenskap en humanisme en meer onlangs, die persoonlike vryheid van die individu, wakker hierdie oordrewe klem op materiële sukses aan.

Afgesien van die oordrewe klem op inkomste is die toenemende graad van mededinging 'n verdere faktor wat bydra tot die etiese dilemmas in die sakewêreld. Verhoogde mededinging plaas die druk op lae koste en kort tydskedules, ten einde bepaalde inkomstesyfers te behaal en te handhaaf. Dit skep die teelaarde vir praktyke wat oneties is juis vanweë onetiese kortpaaie wat weer tot ' $n$ totale morele krisis kan lei.

Etiese probleme is die resultaat van menslike gedrag. Die oplossing verg kreatiewe denke en doeltreffende etiese leierskap. In 'n groot deel van die Westerse wêreld word etiek (en daarom ook sake-etiek) in die Christelike geloof gefundeer. Dit is ook hierdie fundamentele uitgangspunt wat in hierdie artikel beklemtoon word. Etiese leierskap dus, soos dit hier behandel word het sy verankering in die Christelike geloof.

Etiese leierskap is op die volgende gegrondves:

- Dat die besluite wat bestuurders neem, versoenbaar moet wees met die doelstellings van die onderneming en mag nie die waardestelsel van die individu aantas nie.
- Dat etiese beginsels daargestel moet word ten einde verantwoordelike leierskap te beoefen sonder om na 'n substituut vir persoonlike verantwoordelilkheid in besluitneming te soek (Enderle, 1987, p. 657). Besluitneming is 'n gewetensaak. Die gevoelens wat deur die besluit opgewek word, word sterk deur die waardestelsel van die besluitnemer beïnvloed. As die besluitnemer se lewensvisie Christelikgefundeerd is, sal die norme soos afgelei uit die Wet van God, die basis wees waarop die besluit beoordeel gaan word (De Klerk, 1991, p. 558).

Daar is bekendes in die sakewêreld wie se standpunt hieromtrent geen geheim is nie. Hierdie sakeleiers toon 'n bereidheid om hul integriteit en hoë standaarde van moraliteit uit te leef en ook om dit onomwonde in die openbaar te verklaar (De Klerk, 1991, p. 542). De Bruyn (1986, p. 14) stel dit so: “Goeie integriteit was nog altyd noodsaaklik vir goeie sake en daar is geen beter lees om daardie integriteit op te skoei as juis die Christenskap nie: in wese is bestuur die resultate wat deur mense behaal word, en daar is geen beter stel reëls as die Tien Gebooie van God nie. Trouens die Christenskap is die hoeksteen vir goeie resultate, wat weer goeie bestuur weerspieël." Geertsema (1985, p. 69) stel eweneens: "Die winsmotief en Christelike bestuursetiek is nie strydig met mekaar nie. Die winsmotief is in der waarheid ' $n$ integrale deel van die Christelike etiek. Sonder 'n gesonde strewe na wins sal die Christelike bestuurder kwalik sy roeping ten volle kan vervul."

\section{UITGANGSPUNTE}

Om te besin oor etiek vra tegelyk besinning oor die grondslag waarop dit gebaseer gaan word. In hierdie artikel is die grondslag soos aangedui die Christelike uitgangspunt soos dit in die reformatoriese tradisie voorkom.

Dit is derhalwe belangrik dat die volgende deurgaans in gedagte gehou word:

Daar bestaan geen enkele grondreël wat vir alle etiese probleme sal geld nie. Dit is moeilik om te bewys dat enige persoon se maatstawwe beter as dié van die vorige een s'n is. Wat gedoen moet word, word deur die oortuigingsraamwerk van die betrokke persoon bepaal. Selfs binne geledere van 'n homogene groep met dieselfde religieuse grondslae kan daar interpretasieverskille wees. Dit is dus die verantwoordelikheid van elke persoon om volgens die aanvaarde etiese beginsels 
op te tree. Vir die Christen is die maatstaf die beginsels soos in die Woord van God vervat (De Klerk 1991, p. 555).

Die bestaan van die sogenaamde "goue reël" word deur baie mense aanvaar. ("Doen aan ander soos jy aan jouself gedoen wil hê."). Die "goue reël" is in ooreenstemming met die Christelike norme maar in die toepassing daarvan is dit totaal mensgerig en gewoon humanisties van aard. Dit is ' $n$ horisontale siening en het bloot op die intermenslike vlak betekenis met 'n bedekte element van egoïsme (Bensman, 1967, p. 51). Met die goue reël word die prinsipiële grondslag van etiese optrede afgewys.

Etiek moet toegevoeg word tot die bestuurder se "gereedskapkas" ten einde 'n mededingende voordeel te bewerkstellig.

In die Ekonomiese en Bestuurswetenskappe is die skeiding tussen reg en verkeerd nie so klinkklaar nie. Akademici en sakelui wat erns met hul Christenskap wil maak sal dieper as die oënskynlike moet delf om antwoorde op die wesensvrae te kry.

Onderrig in bestuursetiek behoort ' $n$ integrale deel te vorm van bestuursopleiding en ontwikkeling.

Die dosent se optrede en gedrag is net so belangrik as sy mondelinge mededelings.

Binne die raamwerk van genoemde uitgangspunte word daar aandag geskenk aan: (i) Die beantwoording van die vraag of bestuursetiek onderrig kan word en indien wel die trefwydte daarvan en (ii) 'n Toekomsblik op die onderrig van bestuursetiek. Binne die konteks word die benadering tot die onderrig, die inhoud, die rol van die student en die verantwoordelikheid van die opvoeder (dosent) in besonder bekyk.

\section{DIE PROBLEEM VAN KRUISKULTURELE ETIEK EN POLARISASIE VAN WÊRELDBESKOUINGE}

Tsalikis en Nawachukwu (1988, p. 745) wys op die probleem van "cross cultural ethics". Selfs Engeland (1975) en McClleland (1961) is beide van mening dat verskillende kulture nie noodwendig dieselfde invloed op sakepraktyke het nie. Dit is duidelik dat die etiese persepsies van verskillende kultuurgroepe van mekaar verskil. In die heterogene Suid-Afrikaanse samelewing is dit nie realisties om die handhawing van homogene etiese norme van almal te verwag nie. Hierdie verskille in morele standaarde kan ook binne 'n bepaalde kultuurgroep voorkom. So kan ook ouderdomsverskille morele standaarde tot gevolg hê. Die rede waarom daar sulke verskille bestaan, is gesetel in die feit dat elke mens 'n oortuigingsraamwerk het wat sy siening van die werklikheid en die lewe beïnvloed. 'n Oortuigingsraamwerk word ontwikkel deur al die samelewingsverbande waaraan die individu blootgestel word.

Dit bring 'n mens voor die dilemma van die sogenaamde etiese relatiwiteit. Morele standaarde tussen kultuurgroepe verskil en die optrede wat vir die een groep aanvaarbaar is, is vir die ander totaal onaanvaarbaar (De Klerk, 1991, p. 544). Boatright (1993, p. 22) noem dit kulturele relatiwiteit. Hy bepleit, veral by bestuur, ' $n$ begrip en groter verdraagsaamheid ten opsigte van die verskil in morele standaarde. Boatright (1993, p. 23) sê: “. . . tolerance allows us to engage in rational discussion with people who hold contrary views, thus allowing everyone an opportunity to correct any mistaken beliefs. The obligation to understand ... are wholly compatible with the possibility of justification in ethics". Eenstemmigheid in etiek is ' $n$ onrealistiese verwagting. Die beste weg om op te gaan is om die vraagstukke te analiseer, die feitlike deeglik te bestudeer, klaarheid te verkry en dan argumente te ontwikkel ten einde tot 'n korrekte konklussie te kom. In die woorde van Boatright (1993, p. 18): "Business ethics is simply the attempt to think clearly and deeply about ethical issues in bus- iness and to arrive at conclusions that are supported by the strongest possible arguments."

'n Verdere realiteit is dat daar oor jare heen 'n duidelike klemverskuiwing gekom het, weg van die sogenaamde klassieke wêreld beskouing ("classical world view") na die meer moderne beskouing: ' $n$ siening van godsdienstige skeptisisme, godsdienstige ongehoorsaamheid, individualisme, selfbelang, bevryding, individuele moraliteit en die sogenaamde "oorlewing van die sterkste" (Walton, 1977, p. 17). Die kenmerke van hierdie klemverskuiwing kan kortliks soos volg saamgevat word:

TABEL 1

'N VERGELYKING VAN DIE KLASSIEKE EN MODERNE WÊRELD BESKOUINGS

\begin{tabular}{|c|c|}
\hline Klassieke Wêreldbeskouing & Moderne Wêreldbeskouing \\
\hline \multicolumn{2}{|l|}{ (Grieks-Romeins en Christendom) } \\
\hline • Religieuse geloof & - Religieuse skeptisisme \\
\hline - Doel ("Ends") & - Metode ("Means") \\
\hline - Gesentraliseerde gesag & - Gedesentraliseerde gesag \\
\hline • Intuïsie & - Rasionalisasie \\
\hline - Religieuse gehoorsaamheid & - Religieuse afkeur \\
\hline - Sin vir gemeenskaplikheid & - Sin vir individualisme \\
\hline - Geseënd is die armes & - Geseënd is die welgesteldes \\
\hline - Liefdadigheid & - Eiebelang \\
\hline - Medelye & - Oorlewing van die sterke \\
\hline - Geregtigheid & - Vryheid \\
\hline - Roetine, gewoonte & - Innovasie \\
\hline - Stabiliteit & - Mobiliteit \\
\hline - Statiese ekonomie & - Groeiende ekonomie \\
\hline - Regverdige prys & - Markprys \\
\hline - Toekomstige wêreld oriëntasie & - Huidige wêreld oriëntasie \\
\hline
\end{tabular}

(Walton, 1977, p. 17)

Dit is opmerklik dat die klemverskuiwing, van die klassieke na die moderne, saamloop met die verskuiwing van die tweede-geslag na die derde-geslag ondernemings wat deur Toffler se "Future shock" en Naisbitt in "Megatrends" voorspel is. Schulley (1987, p. 136) beskryf dit as die derde-golf bestuur ("managerial third wave"). Die vermoë om aan te pas by verandering is dan ook die grootste enkele verskil tussen tweede- en derde-golf ondernemings. Die kontrasterende bestuurseienskappe wat in tweede-geslag versus derde-geslag ondernemings verwag word, word in Tabel 2 voorgestel.

TABEL 2

KONSTRASTERENDE BESTUURSEIENSKAPPE

\begin{tabular}{lll}
\hline Bestuursdimensie & \multicolumn{1}{c}{ Tweede-geslag } & \multicolumn{1}{c}{ Derde-geslag } \\
\hline Organisering & Hiërargies & Netwerk \\
Uitset & Markaandeel & Markskepping \\
Fokus & Onderneming & Individu \\
Styl & Struktureerd & Buigbaar \\
Bron van krag & Stabiliteit & Verandering \\
Struktuur & Self-onderhoudend & Interafhanklik \\
Kultuur & Tradisie & Genetiese kode \\
Missie & Doelwitte/Strategiese planne & Identiteit/Rigting/Waardes \\
Leierskap & Dogmaties & Inspirerend \\
Kwaliteit & Bekostigbare beste & Geen kompromie \\
Verwagtings & Sekuriteit & Maak van 'n verskil \\
Hulpbronne & Kontant & Inligting \\
\hline
\end{tabular}

Volgens Toffler (Sculley, 1987, p. 136) word die derde-golfbestuursbenadering gekenmerk deur geïnspireerde leierskap, 
persoonlike groei, individualisme en 'n genetiese kode wat gebou word op identiteit, rigting en waardes.

Die verskil tussen tweede- en derde-golf ondernemings is besig om steeds meer kritiek te raak soos die tempo van verandering toeneem en as gevolg van die versnelling van die inligtingsera.

Dit is belangrik om te begryp dat etiese relatiwiteit in bestuursbesluite ' $n$ belangrike rol speel. Daar bestaan nie algemeen aanvaarde reëls in die sake-etiek nie: elke sakeman oordeel volgens sy eie insig. Elke mens het 'n oortuigingsraamwerk wat sy siening van die werklikheid en die lewe beïnvloed. In die bedryfslewe sal elke persoon erns moet maak met sy religieuse verbondenheid in die besluite wat geneem word, gelei deur 'n persoonlike oortuigingsraamwerk.

\section{DIE NOODSAAKLIKHEID EN BEPERKINGS VAN DIE ONDERRIG VAN BETUURSETIEK}

Op die vraag of bestuursetiek onderrig kan word is die antwoord onomwonde, ja. Dit moet 'n leerervaring vir die student wees. Binne die konteks van die onderrig van bestuursetiek stel Weber (1990, p. 183) dit soos volg: "We can do little to lead off the 'bad apple' . . . but, we can help prepare the good MBA's to manage the strength of their own character in any business career, and in their role as managers, to create a supportive ethical environment for their subordinates."

Dit is belangrik dat kennis geneem word van die bepaalde beperkings wat geld in die onderrig van bestuursetiek want dit sal uiteindelik ' $n$ invloed hê op die benadering wat gevolg behoort te word. Die volgende beperkings kan geïdentifiseer word:

- Die problematiek van die regte balans tussen ekonomiese resultate en etiese verantwoordelikheid (Weber, 1990, p. 186).

- Daar word beweer dat bestuursetiek in sy aard nie-empiries en as gevolg daarvan nie wetenskaplik is nie. Etiese besluite word op 'n subjektiewe wyse geneem (Weber, 1990, p. 186).

- Die tydrowendheid en ingewikkeldheid van die onderrig.

- Die gebrek aan ervaring by dosente betrokke by die onderrig. Akademici verstaan nie die etiese vraagstukke en dilemmas wat deur die studente in die werkplek ervaar word nie (Strong \& Hoffman, 1990, p. 603). Dosente tree nie op in belang van die studente as filosofies-etiese modelle aan hul voorgehou word nie.

Ongeag die beperkings wat ten grondslag van die onderrig van bestuursetiek lê, lê die noodsaaklikheid van opleiding in bestuursetiek in die volgende navorsingsbevindings soos deur die literatuur weergegee: (Strong \& Hoffman, 1990, p. 603; Segal, 1992, p. 11 en Weber, 1990, p. 186).

- Etiek het 'n positiewe invloed op loopbaansukses.

- Etiese problematiek strek veel verder as formele en amptelike pligte en verantwoordelikhede. Blote gehoorsaamheid aan landswette en ordonansies is nie voldoende nie.

- Die onderrig in bestuursetiek maak 'n positiewe bydrae tot die verbetering van morele/etiese gedrag.

- Bestuursetiek moet geïntegreer word in bestuursopleiding. Die felste kritiek wat tans teen bestuursopleiding uitgespreek word, is dat daar 'n gebrek aan opleiding is in die sogenaamde "soft subjects" wat bestuursetiek insluit.

- Etiek is 'n beheermeganisme in die hantering en omgang met werknemers en verbruikers.

Wat betref die trefwydte van bestuursetiek, is dit belangrik om te wys op die studie van Van Jaarsveld (1988, p. 139). Van Jaarsveld (1988, p. 139) toon duidelik hoe belangrik bedryfsetiese vraagstukke in die RSA beskou word. Die ondersoek aan bestuurskole in die RSA het getoon dat die meeste deelgebiede ' $n$ bedryfsetiese implikasie het soos in Figuur 1 aangedui.
Figuur 1: Die belangrikheid van etiese verantwoording in die onderneming.

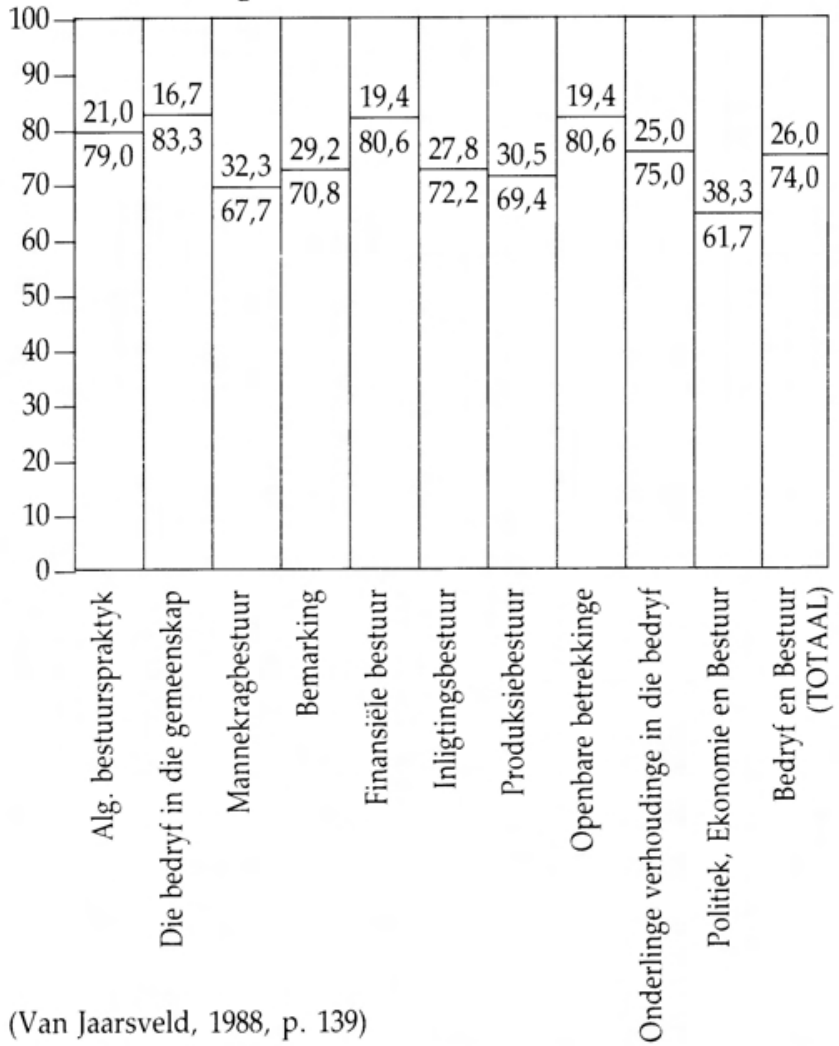

Die meerderheid respondente $(74 \%)$ in dié ondersoek het aangedui dat die temas soos aangedui in Figuur 1 wel relevant is ten opsigte van besigheids- of sake-etiek. Respondente stem ook saam dat 93,8 persent van die gelyste temas wel ingesluit moet word in die kurrikula van bestuurskursusse en programme. Slegs 47,8 persent van die respondente het aangedui dat die temas reeds in bestuurskursusse geakkommodeer word, terwyl 11,9 persent van die bestuurskole wel beplan het om dit vanaf 1988 deel van hulle bestuursprogramme te maak. Dit is dus duidelik dat die oorgrote meerderheid van temas wel 'n bedryfs-etiese implikasie het.

Ook De Klerk (1991, p. 555) verwys na die trefwydte van bestuursetiek as hy sê: "Bestuursetiek is 'n omvattende en dinamiese taak en voortdurende besinning en aanpassing is 'n noodsaaklike voorvereiste vir eties-verantwoorde bestuur."

Die toedrag van sake beklemtoon net die belangrikheid van bestuursetiese onderrig en dat daar met dringendheid aandag aan dié faset van die opleiding gegee moet word.

Dit moet in gedagte gehou word dat die volgende generasie sakeleiers tans by Bestuurskole opgelei word. Segal (1992, p. 11) rapporteer dat daar elke jaar deur die sewe bestaande Bestuurskole in Suid-Afrika ongeveer 550 MBA's "afgelew$\mathrm{er}^{\prime \prime}$ word. Om suksesvol te wees, is dit nodig dat die studente hul totaal verbind tot hoë etiese standaarde. Die bestuurslui van môre is diegene wat verantwoordelik sal wees vir die etiese kode (binne die onderneming) wat opgestel en verfyn moet word. Sodanige kode behoort klaarheid te gee aan etiese sake maar laat wel ruimte vir die individu om oplossings te soek binne die raamwerk van sy eie gewete. Daar moet toegesien word dat die kode duidelike prioriteite stel en nie bloot etiese reëls tot die bestaande agenda toevoeg nie. Om te dink dat 'n etiese kode ' $n$ vaste grond bied vir morele optrede is bloot spekulasie en naïef.

\section{DIE STRUKTURERING EN INHOUD VAN DIE ONDERRIG}

In die strukturering van die onderrig van bestuursetiek is dit belangrik om die multi-dissiplinêre aard van bestuursopleiding in gedagte te hou. Dit wissel van konseptueel toe toege- 
pas, van kwantitatief tot kwalitief, van filosofies tot pragmaties, van histories tot toekomsgerig en van sakeverwante aspekte tot die totale sosio-politieke spektrum. Die oorhoofse doel van bestuursopleiding word deur Van Vuuren (1989, p. 4) soos volg gestel: ". . . to increase the competence of managers and those who would be managers - since business management is an intelligent form of human activity; not intellectual nor academic, but practical in nature". Sulcas (1989, p. 2) rapporteer in die verband die volgende: "Research findings published by the Human Sciences Research Council in 1987 list the motives why people apply to study for a Master of Business Administration or an equivalently designed degree. The degree is perceived to be important for learning management skills $(32,9 \%$ of sample), gaining promotion $(25,5 \%)$, advancing managerially in technically orientated fields such as engineering $(14,8 \%)$, and improving qualifications $(14,8 \%)$."

In die benadering tot die onderrig van bestuursetiek is ' $n$ gefragmenteerde siening van die mens nutteloos. Dit is nodig om alle fasette van die mens in berekening te bring. Die totaliteits- of komprehensiewe benadering wil juis die klem op al die fasette van die mens laat val.

Dié totaliteitsbenadering verskil duidelik van die behaviouristiese standpunt waar die mens se gedrag bepaal word deur bepaalde impulse en reaksies. Ander strominge beklemtoon weer die sosiale of omgewingsfaktore wat menslike gedrag bepaal. Die evolustiese benadering soek weer na konsepte soos "die oorlewing van die sterkste" en "natuurlike seleksie". Die bestudering van ' $n$ besondere faset van die mens se lewe as verklaringsgrond vir die hele mens is onaanvaarbaar. 'n Ongefragmenteerde siening moet dan ook in die wetenskapsbeoefening ingebou word en die student, die toekomstige bedryfsleier, moet daarin geskool word.

Die multi-dissiplinêre aard van bestuursopleiding, die oorhoofse doel en die ongefragmenteerde benadering tot die onderrig noop die meerderheid skrywers (Etzioni, 1989, p. 19; George, 1987, p. 513; David, 1990, p. 27; Pamental, 1989, p. 547 \& Singh, 1989, p. 52) tot die gevolgtrekking dat 'n selfstandige kursus nie die antwoord is nie. In 'n studie wat gedurende 1987 deur die American Assembly of Collegiate schools of Business (AACSB) in die VSA gedoen is, is bevind dat 53,2 persent van die bestuurskole ' $n$ totale integrasie van bestuursetiek in bestaande kursusse voorstaan (George, 1987, p. 515). 'n Selfstandige kursus in die bestuursetiek word afgemaak as kompartementalisering met min en geen waarde (Pamental, 1989, p. 547). 'n Soortgelyke studie deur van Jaarsveld (1989, p. 139) wys daarop dat $47,8 \%$ van Suid-Afrikaanse bestuurskole integrasie voortaan, terwyl 11,9 persent beplan om dit wel te integreer.

In 'n studie aan die Randse Afrikaanse Universiteit deur die Departement Ondernemingsbestuur, (1992) is bevind dat 65,5 persent van die respondente ' $n$ integrasie van bestuursetiek by die ander kursusse voorstaan. Dit teenoor 34,5 persent wat eerder voel dat ' $n$ selfstandige kursus in die bestuursetiek die aangewese weg is om te volg.

Van die 36 respondente wat 'n geïntegreerde benadering tot die onderrig van bestuursetiek voorstaan voel 97,2 persent dat baie aandag aan gemeenskapsverhoudinge geskenk moet word terwyl 94,4 persent van dié respondente voel dat die openbaarmaking van onetiese gedrag beslis aandag behoort te geniet. Al die respondente is dan ook van mening dat daar goeie rede bestaan dat die sakepraktyk meer eties oor 10 jaar sal wees as wat dit nou die geval is. Van die respondente wat 'n geïntegreerde benadering tot bestuursetiek voorstaan is 91,7 persent van mening dat daar tans ' $n$ opgradering van etiese norme behoort plaas te vind. Slegs 8,5 persent het negatief op dié betrokke vraag gereageer.

Die oorhoofse doel met die onderrig in bestuursetiek is om by te dra tot die etiese ontwikkeling van studente (ingeslote in die missiestelling van die betrokke bestuurskool of departe- ment). Hierdie leerdoelwitte word deur Reeves (1990, pp. 610-612) in die volgende fases verdeel:

- die bewusmaking daarvan dat etiese oorwegings 'n rol speel in bestuursbesluitneming;

- die bevestiging van etiese oorwegings as 'n integrale deel van die bestuursbesluit;

- die voorsiening van 'n konseptuele raamwerk vir die analise van etiese vraagstukke om huidige en potensiële bestuurders te skool in dié denkraamwerk; (Die vereiste hier is dat die model aanvaarbaar moet wees, verstaanbaar, verbind aan die proses van besluitneming en toepaslik vir die dag tot dag besluitneming.)

- hulp aan studente in die toepassing van etiese norme in hul daaglikse bedrywighede te verleen.

Die daarstelling van 'n konseptuele-analitiese (begripmatige) raamwerk is van primêre belang.

Dit is uiters belangrik dat die ontwikkeling van etiese vaardighede gelyktydig met ander vaardighede van die bestuurder ontwikkel moet word. Pamental (1989, p. 547) en Bassiry (1990, p. 801) en Moulder (1963, p. 63) praat van “. . integrating managerial competence and moral competence . ..". Sodanige konseptuele-analitiese raamwerk word in Figuur 2 voorgestel.

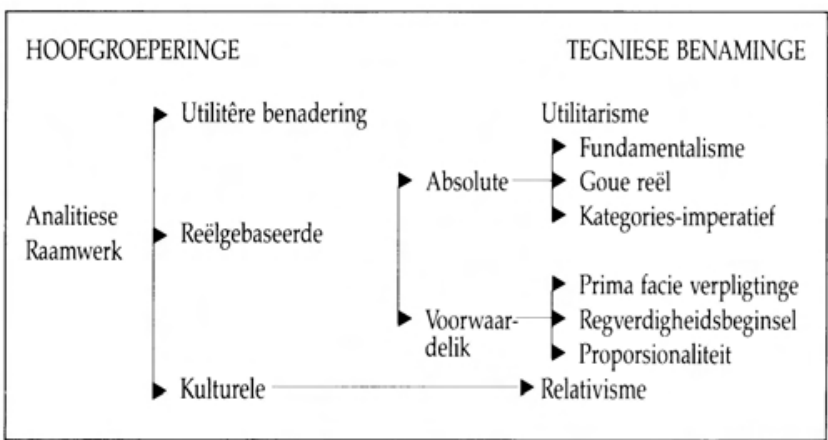

(Gantz en Hays, 1988, p. 666)

\section{Figuur 2: Konseptuele-analitiese raamwerk}

Die utilitêre benadering laat die klem val op die gevolge van die handeling. Die morele waarde van persoonlike optrede word deur die konsekwensies daarvan bepaal. 'n Besluit is reg en goed as dit die grootste moontlike getal mense bevoordeel. Die reëlgebaseerde benadering konsentreer op die absolute teorieë wat voorskriftelik is ten opsigte van wat reg is, die voorwaardelike teorieë wat die 'goue reël' insluit en die fundamentalisme wat 'n enkele universele morele standaard stel van wat reg is.

Wat die relativisme betref bestaan daar nie ' $n$ enkele morele standaard nie, maar eerder 'n stel veranderlike standaarde.

Volgens de Klerk (1991, p. 55) verskaf nie een van bogenoemde denkrigtings ' $n$ bevredigende basis waarop bestuursetiek gegrond kan word nie. Die voor die hand liggende rede is die eensydigheid wat in elke benadering ingebou is.

Die oplossing lê waarskynlik daarin om die onderskeie benaderings in kombinasie in berekening te bring. Die probleem is egter dat dit tot 'n soort noodetiek aanleiding gee. Dit sal weer tot gevolg hê dat die praktyk altyd die optrede bepaal terwyl die beginsel altyd die praktyk behoort te bepaal. Vir die Chirsten lê die antwoord in die Teonome begronding van die besluit(e). Skrifperspektiewe en Skrifwaarhede moet deel wees van die raamwerk waarbinne die besluite afgelei word.

Die bestuurder moet dié analitiese raamwerk gebruik om die etiese vraagstukke aan te spreek. Nie alleen moet bepaalde optrede en besluite geregverdig word nie, maar sal dit ook kritiek in die gebruik daarvan moet deurstaan. 
Die analitiese raamwerk is nie noodwendig volledig nie, maar beklemtoon wel die plurale aard van die gemeenskap waarbinne die onderneming beweeg. Natuurlik moet die gevare van abstraksie en oor-teoretisering besef word.

Dit is gebiedend noodsaaklik dat die analitiese raamwerk geïnkorporeer word by die bestuursbesluitnemingsmodel waarmee bestuurders vertroud is. Die etiese gewete word dan aangespreek deur drie basiese vrae:

a) Wie word geraak deur die besluit?

b) Is dit billik en regverdig teenoor alle betrokke partye?

c) Hoe sal die bogenoemde twee vrae 'n invloed hê op die doelwitte wat gestel is, die alternatiewe wat geformuleer word, die keusebeslissing en die implementering van die besluit?

Hoewel die bestuursanalitiese benadering deur die meeste studente verkies word, is die filosofiese en beskrywende deel van die onderrig net so belangrik en kan dit nie agterweë gelaat word nie.

Benewens bogenoemde behoort die volgende mikpunte nagestreef te word:

* Die student moet die geleentheid gebied word om eie waardes te ontdek. Dit moet egter in gedagte gehou word dat daar geen eties neutrale onderrig bestaan nie. Die realiteit is dat terwyl die onderrig plaasvind en die leerproses in volle gang is, daar kommunikasie plaasvind en 'n bepaalde etiese standpunt word oorgedra.

* Studente moet die vermoë ontwikkel, asook die selfvertroue om nie alleen hul eie motiewe en besluite te bevraagteken nie, maar ook dié van hul kollegas en bestuur.

* Aan die student moet in breë opvoedkundige raamwerk met die beklemtoning van bestuursetiek en sosiale vraagstukke gebied word. Dit impliseer 'n meer multi-dissiplinêre oriëntasie wat meer waarde het as 'n gespesialiseerde kurrikulum. Die skep van 'n eties-analitiese raamwerk binne bestaande strategiese en beleidsaspekte is essensieël.

Deur dié mikpunte na te streef word dit 'n proses waar die student voortdurend 'gevorm en geslyp' word. Die student moet altyd op soek wees na nuwe beginsels en nuwe waardes.

\section{DIE STUDENT EN DIE ROL VAN DIE DOSENT IN DIE ONDERRIGSITUASIE}

Die onderrig en navorsing in bestuursetiek moet ten doel hê om die student te skool in die hantering van etiese problematiek. Segal $(1992$, p. 12) beklemtoon dit deur te sê: "They must be challenged and stretched to develop rather than be trained." Akademici moet die student, die bestuurder in wording, leer om deur middel van geloofswaarhede, Skrifperspektiewe en relevante Skrifwaarhede die onderneming en sy funksionering te verstaan. Wat bereik moet word, is geordende en sistematiese denke oor die verpligting wat op iedereen rus om met verantwoordelikheid op te tree as sakebesluite geneem moet word. Blote intuitiewe optrede is nie goed genoeg nie.

Die student moet besef dat die ekonomiese en etiese nie noodwendig in konflik hoef te wees nie (Pastin, 1988, p. 162). Bestuur moet wegbreek van die gedagte om voortdurend te poog om etiese probleme met suiwer ekonomiese argumente aan te spreek.

Wat die dosent betref in die onderrigproses is dit uiters belangrik dat 'n etiese kode vir die dosent daargestel moet word. Die dosent het ' $n$ waarneembare invloed op die ontwikkeling van die etiese gedrag by studente, nie alleen in wat in die klaskamer gedoen word nie, maar ook hoe die aktiwiteit in die klaskamer bestuur word. Sauer (1990, p. 33) sê: "This code of ethics could help strengthen the moral fibre of future generations of business leaders." Hy noem dit: ". . . the ethics of teaching business". Deur verantwoordelik op te tree, deur 'n goeie voorbeeld te stel, kan die dosent help om daardie gedrag by studente te ontwikkel wat deur die gemeenskap van 'n sakeman verwag word. Deur die aanwending van sodanige kode sal die dosent bewys lewer dat daar erns gemaak word met sake-etiek en die ontwikkeling van positiewe waardes by die student. In Sauser (1990, p. 37) se woorde: "Actions speak louder than words". Die volgende kode kan as uitgangspunt dien:

- Volledige studiehandleidings moet by die eerste ontmoeting beskikbaar gestel word. Dit sluit nie alleen 'n aanduiding van die vakinhoud in nie, maar werkopdragte, doeldatums en algemene reëls wat geld. Verskaf aan student al die nodige relevante inligting ten einde hul in staat te stel om hul werk na behore te doen.

- Hanteer die kurrikulum as 'n kontrak wat in stand gehou moet word. Veranderings kan slegs aangebring word wanneer beide partye daartoe instem.

- Bou die behoeftes en belangstellings van studente in, veral in die werkopdragte.

- Help die student om veral wat werkopdragte betref die teorie en die praktyk volledig te kan integreer. "The distinction should not be between theory and practice; it should be between good theory and bad theory and good practice and bad practice." (Paarlberg, 1969, pp. 24-25.)

- Lesings moet deeglik beplan, goed georganiseer en betekenisvol wees.

- Oudiovisuele hulpmiddels moet van hoë kwaliteit wees en professioneel in aanbieding aangewend word.

- Die student moet aktief betrokke raak in die leerproses. Besprekings, gevallestudies, vraag-en-antwoord-sessies en voordragte is hier van die uiterste belang.

- Behandel studente met die nodige respek. Voortrekkery mag geen rol in die leerproses speel nie. Moet nooit betrokke raak in enige diskriminerende praktyke nie. Seksuele of rassetreitering is allerweë taboe.

- Toetse, werkstukke en eksamens moet versigtig ontwerp, beplan en geadministreer word. Deur vir student werkstukke terug te gee waarop slegs 'n punt verskyn, is onregverdig en oneties. Die student moet ' $n$ aanduiding kry waar gefouteer is.

- Die finale punt vir die betrokke kursus moet die student se kennis en sy/haar optrede in die klas reflekteer.

- Oneerlikheid moet binne die raamwerk van die universiteitsbeleid gestraf word.

- Spoedige terugvoering aan studente van werkopdragte en toetse is ' $n$ asolute vereiste.

Sodanige kode gee rigting, skep 'n gevoel van trots, laat ruimte vir'n simpatieke houding, gee meer perspektief en motiveer die student tot volharding.

\section{ENKELE AANBEVELINGS}

In die lig van die voorafgaande word die volgende breë aanbevelings gemaak:

- Dit is duidelik dat 'n selfstandige kursus in bestuursetiek nie die antwoord is nie maar dat daar eerder ' $n$ integrasie van bestuursetiek in die totale program moet plaasvind.

- Binne die onderrigbenadering moet etiese beredenerings voortdurend versterk word ten einde ' $n$ invloed uit te oefen op bestuursbesluitneming.

- Die dosent moet self die verantwoordelikheid aanvaar vir die onderrig. Die gebruik van "vreemde" departemente soos Filosofie. Bybelstudie of Bybelkunde word nie as wenslik beskou nie. Die vermoë van dié departemente word geensins betwyfel nie, maar die gebruik van "eie dosente" skep groter geloofwaardigheid.

- Dosente in die verskillende deelgebiede moet opgelei word om etiese analise by hulle vak te integreer, so nie sal die dosent en die betrokke kursus kredietwaardigheid inboet. Hiermee moet daar met groot erns begin word. 'n Opleidingprogram moet ingestel wees op die uitskakeling van vrees rondom die hantering van etiese vraagstukke, asook om die dosent se analitiese vaardighede op dié gebied te ontwikkel.

- Vanuit akademiese kringe behoort daar 'n gekoördineerde multi-dissiplinêre poging aangewend te word om die veld van bestuursetiek binne die wetenskapetiek te sistematiseer en te formaliseer. 
Ten minste een dosent behoort afgesonder te word om as bron te dien in die opleiding van dosente. Dit is die taak van hierdie "tutor" om:

* Saam met die span te besluit op 'n aanvaarbare analitiese raamwerk;

* Hulp te verleen met die identifisering van krities-etiese vraagstukke in die verskillende deelgebiede. Hier lê die uitdaging in die bewus wees van die vraagstukke van die tyd. Hou in gedagte dat die vraagstukke verander soos wat die sosiale waardes verander.

- Betrokke bestuurskole en institute moet op 'n gekoördineerde wyse navorsing doen deur die plaaslike situasie te analiseer en daarvolgens ' $n$ verantwoordbare veld vir bestuursetiek, met die nodige akademiese onderbou op te stel.

- Bestuursetici moet betrokke raak by opleidingsprogramme in ondernemings. Suid-Afrikaanse ondernemings moet aangemoedig word om met in-huis opleiding te begin.

- Daar moet beweeg word in die rigting van 'n navorsingseenheid in bestuursetiek (sentrum in bestuursetiek) met as oogmerke die daarstelling van 'n adviesdiens en hulp met kursusontwikkeling. Alle universiteite en betrokke institute behoort hieraan deel te hê. Sodanige sentrum behoort ' $n$ bewusmakingsprogram van stapel te stuur deur publikasies en simposia.

Alhoewel reeds baie in die verband deur verskillende bestuurskole gedoen is, is dit uiters belangrik dat 'n meer gekoördineerde poging tot onderrig in bestuursetiek van stapel gestuur word. Nie net reaktiewe moraliteit nie maar eerder meer proaktiewe moraliteit. Die onderrig van bestuursetiek as deel van bestuursopleiding is wesensbelangrik en is dit die nodige aandag, beplanning en investering waardig.

Soos Luoma (1989, p. 16) van die Universiteit van South Carolina dit stel: "For too long the phrase business ethics has been viewed as a oxymoron - a contradiction in terms - like hot chili - It's time to make the phrase respectable again."

\section{VERWYSINGS}

Bassiry, C.R. (1990). Ethics, education and corporate leadership. Journal of Business Ethics, 9(10), 799-805.

Bensman, J. (1967). Dollars and sense. New York: Macmillan.

Boatright, J.R. (1993). Ethics and the conduct of business. Englewood Cliffs: Prentice Hall.

Boshoff, A.B.; Du T. Smith, S.; Moore M.L. \& Rautenbach, K. (1987). South African managerial values. Proceedings of the Pan-Pacific Management Conference, 639-644.

Carroll, A.B. (1987). In search of the moral manager. Business Horizons, 7-15.

Coman, K.R. (1992). Business ethics in South Africa: an investigation of managerial perceptions and attitudes. The fourth conference of the Southern Africa Institute of Management Scientists, Vista University, Bloemfontein, RSA, pp.22-23.

David, F.R.; Anderson, L.M. \& Lawrimore, K.W. (1990). Perspectives on Business ethics in Management education. SAM Advanced Management Journal, 55(2), 26-32.

De Bruyn, W. (1986). Oortuiginge en Christenskap skuif dan die binnekamer na die jaarverslag. Finansies en Tegniek, 38/1.

De Klerk, G.J. (red.) Bedryfsetiek, Deel III. (Diktaat) P.U. vir C.H.O.

De Klerk, G.J. (1991). Bestuursetiek. Koers, 56(4), 541-560.

De Klerk, G.J. (1991). Bedryfsetiek. Deel 1. Potchefstroom: P.U. vir C.H.O.

Dolenga, H.E. (1990). An inconoclastic look at business ethics. Advanced Management Journal, 55(2), 13-17.

Donaldson, T. \& Werhane, P.H. (1988). Ethical issues in business: a philosophical approach. Englewood Cliffs: Prentice-Hall.

Enderle, G. (1987). Some perspectives of managerial ethical leadership. Journal of Business Ethics, 9(1), 657-663.

England, G.W. (1975). The manager and his values: an international perspective. Cambridge: Ballinger Publishing.
Etheridge, D.A. (1982). Developing strategies to combat corruption. Pretoria: Referaat gelewer op 2 Augustus 1983 tydens UNISA se seminaar oor korrupsie.

Etzioni, A. (1989). Are business schools brainwashing their MBA's. Business and Society Review, 70(1), 18-19.

Gandz, J. \& Hayes, N. (1988). Teaching business ethics. Journal of Business Ethics, 7(9), 657-69.

Geertsema, A. (1985). Die winsmotief en Christelike bestuursetiek. (Skripsie (MBA) - P.U. vir C.H.O.)

George, R.J. (1987). Teaching business ethics: Is there a gap between rhetoric and reality. Journal of Business Ethics, 6(7), 513-518.

Halford, J. (1990). Should business schools be Sunday schools? Business and Society Review, 71(2), 54-55.

Hosmer, L.T. 7 Steneck, N.H. (1989). Teaching business ethics: the use of films and videos. Journal of Business Ethics, 8(12), 929-936.

Longenecker, J.G., McKinney, J.A. \& Moore, C.W. (1989). The generation gap in business ethics. Business Horizons, 9-14.

Luoma, G.A. (1989). Can ethics be taught? Management Accounting. 71(11), 14-16.

McClelland, D.C. (1961). The achieving society. New Jersey: Van Nostrand.

Moulder, D.C. (1989). Towards a new curriculum for business ethics: exploring questions about values and wealth in a South African MBA programme. South African Journal of Philosophy, 8(2), 77-87.

Paarlberg, D. (1969). Great myths of economics. Ohio: The New American Library.

Pamental, G.L. (1989). The course in business ethics: can it work? Journal of Business Ethics, 8(5), 547-551.

Pastin, M. (1988). The hard problems of management: gaining the ethics edge. Journal of Business Ethics, 7(3), 162-163.

Reeves, M.F. (1990). An application of Blooms' Taxonomy to the teaching of business ethics. Journal of Business Ethics, 9(7), 609-616.

Sauser, W.I. (jr). (1990). The ethics of teaching business: toward a code of business professors. Advanced Management Journal, 55(2), 33-37.

Sculley, J. (1987). Odyssey: Pepsi to Apple. Glasgow: Fontana/Collins.

Segal, S. (1992). Business school graduate: learning curve rises for new generation of SA Management. Finance Week, 53(1), 11-12.

Singh, J.B. (1989). The teaching of ethics of Canadian Schools of management and Administrative studies. Journal of Business Ethics, 8(1), 51-56

Strong, V.K. \& Hoffman, A.N. (1990). There is relevance in the classroom: analysis of present methods of teaching business ethics. Journal of Business Ethics, 9(7), 603-607.

Sulcas, P. (1988). The future of business schools in South Africa: inaugural lecture. University of Cape Town.

Tsalikis, J. \& Nwachukwu, O. (1988). Cross-cultural business ethics: ethical beliefs difference between blacks and whites. Journal of Business Ethics, 9(7), 745-754.

Van Jaarsveld, B.J. (1988). The theory and practice of business ethics in South Africa: a status report. Suid-Afrikaanse Tydskrif vir Hoër Onderwys. 2(1), 139-142.

Van Vuuren, M.J.C. (1989). Hoëvlak bestuursopleiding in SuiderAfrika - standpunte, probleme en geleenthede: intreerede: Departement Bestuurswese, Fakulteit Ekonomiese en Bestuurswetenskappe, Universiteit van Pretoria. Pretoria: Van Schaik.

Walton, C.C. (1977). The ethics of corporate conduct. Englewood Cliffs: Prentice-Hall.

Weber, J. (1990). Measuring the impact of teaching ethics to future managers: a review, assessment and recommendations. Journal of Business Ethics, 9(3), 183-190.

Weller, S. (1988). The effectiveness of corporate codes of ethics. Journal of Business Ethics, 7(5), 389-395. 